\title{
Stan wiedzy oraz występowanie trądziku (Acne vulgaris) wśród młodzieży w Szczecinie
}

\section{State of knowledge and the prevalence of acne (Acne vulgaris) among young people in Szczecin}

\author{
Karolina Jakubczyk¹, Katarzyna Janda², Magdalena Chwiłkowska³, Jolanta Wolska² \\ 1 Studium Doktoranckie Wydziału Nauk o Zdrowiu Pomorskiego Uniwersytetu Medycznego w Szczecinie \\ ul. Żołnierska 54, 71-210 Szczecin \\ Kierownik: prof. dr hab. n. med. Maria Laszczyńska \\ ${ }^{2}$ Zakład Biochemii i Żywienia Człowieka Pomorskiego Uniwersytetu Medycznego w Szczecinie \\ ul. Broniewskiego 24, 71-460 Szczecin \\ Kierownik: prof. dr hab. n. med. Ewa Stachowska
}

${ }^{3}$ Absolwentka Wydziału Nauk o Zdrowiu Pomorskiego Uniwersytetu Medycznego w Szczecinie

ul. Żołnierska 48, 71-210 Szczecin

Dziekan: prof. dr hab. n. zdr. Beata Karakiewicz

\section{SUMMARY}

Introduction: Acne vulgaris is a chronic disease associated with dysfunction of the sebaceous glands and the hair follicles. The disorder affects approximately $80 \%$ of the Polish youth population and has become an important clinical issue.

The aim of this study was to examine the state of knowledge about acne among youth in Szczecin, and to attempt to identify the main causes of the disease.

Material and methods: The study was conducted among 100 young people in Szczecin aged 12 to 25 years. A validated questionnaire was used for the research.

Results: The questionnaire analysis showed that acne affects $60 \%$ of the surveyed young citizens of Szczecin. The study shows that the prevalence of acne depends on the type of skin, tendency to have skin imperfections, and the age of the respondents. Knowledge of skin care, factors affecting the occurrence of acne, and treatments used depend on the age of respondents. The greatest awareness was found among older students and the smallest among secondary school students.

Conclusions: knowledge about prevention, treatment and skin care is still insufficient, and therefore there is a great need to educate and raise the awareness of young people.

Key words: acne, young people.

\section{STRESZCZENIE}

Wstęp: Trądzik pospolity (Acne vulgaris) to przewlekła choroba gruczołów łojowych i ujść mieszków włosowych o podłożu zapalnym. Obecnie schorzenie to dotyczy głównie młodej populacji i występuje u ok. $80 \%$ polskiej młodzieży, stanowiąc istotny problem

Celem pracy było sprawdzenie stanu wiedzy na temat trądziku wśród młodzieży w Szczecinie oraz próba określenia głównych przyczyn występowania choroby.

Materiał i metody: Badanie przeprowadzono na 100-osobowej grupie szczecińskiej młodzieży w wieku 12-25 lat. Jako narzędzie badawcze zastosowano walidowaną ankietę.

Wyniki: Dzięki badaniom ankietowym dotyczącym stanu wiedzy na temat trądziku wśród młodzieży w Szczecinie oraz występowania choroby dowiedziono, iż schorzenie to występuje powszechnie i dotyczy ok. $60 \%$ ankietowanych. Występowanie trądziku uzależnione jest od rodzaju posiadanej cery, jej skłonności do niedoskonałości i wieku respondentów. Wiedza na temat pielęgnacji, czynników wpływających na występowanie tej dermatozy oraz stosowanie środków leczniczych uzależniona jest głównie od wieku respondentów. Największym zasobem informacji dotyczącym tych zagadnień cechowali się studenci, najmniejszym zaś młodzież gimnazjalna.

Wnioski: Wiedza na temat profilaktyki, leczenia i pielęgnacji skóry w tej chorobie jest niewystarczająca, dlatego tak ważna jest odpowiednia edukacja i poszerzenie świadomości młodzieży. Słowa kluczowe: trądzik, młodzież.

\section{WSTĘP}

Trądzik pospolity (Acne vulgaris) jest przewlekłym, szeroko rozpowszechnionym schorzeniem o podłożu wieloczynnikowym. Stanowi duży problem terapeutyczny, psychologiczny i społeczny. Choroba występuje w okolicach bogatych w gruczoły łojowe, charakteryzuje się łojotokiem, tworzeniem zaskórników, krostek zapalnych, grudek i blizn [1]. Acne vulgaris definiowany jest również jako stan zapalny aparatu gruczołu łojowego i mieszka włosowego o przewlekłym 
przebiegu [2] bądź jako przewlekła zapalna choroba gruczołów łojowych i ujść mieszków włosowych, charakteryzująca się występowaniem wykwitów niezapalnych i zapalanych [3]. Trądzik pospolity uznawany jest powszechnie za bardzo częste zjawisko. Dotyczy głównie okolic łojotokowych, w 99\% przypadków występuje na twarzy. Ocenia się, że choroba ta dotyczy $80 \%$ młodzieży i może być przyczyną pojawienia się stresu, depresji oraz lęku [4]. Największa zapadalność przypada na okres dojrzewania, mimo to schorzenie może się rozwijać zarówno przed okresem pokwitania, jak i utrzymywać w wieku dorosłym [3]. Acne vulgaris jest chorobą wieloczynnikową, obejmującą zarówno czynniki zewnętrzne, jak i wewnętrzne. Należą do nich czynniki genetyczne, wytwarzanie łoju, hormony, bakterie i właściwości mieszków łojowych. Rola czynników immunologicznych w przypadku trądziku jest drugorzędna. Zarówno w przeszłości, jak i obecnie trądzik stanowi duży problem oraz dotyka coraz większej liczby osób. Uzyskanie informacji o przyczynach jego powstawania w obecnych czasach może stanowić istotny czynnik wpływający na skuteczną profilaktykę oraz leczenie tego schorzenia [5].

Celem pracy było sprawdzenie za pomocą badania ankietowego stanu wiedzy na temat trądziku wśród młodzieży w Szczecinie oraz próba określenia głównych przyczyn występowania choroby.

\section{MATERIA I METODY}

Jako narzędzie badawcze zastosowano ankietę, która była przeprowadzona na 100-osobowej grupie szczecińskiej młodzieży w wieku 12-25 lat.

\section{Opis walidacji - oceny rzetelności ankiet}

Walidacja ankiety została przeprowadzona po jej wypełnieniu przez 100 osób. Grupą badaną była młodzież gimnazjalna, licealna oraz studenci ze Szczecina. Losowo wybrane osoby wypełniły kwestionariusze 2-krotnie w 7-dniowym odstępie czasu. Tylko prawidłowo wypełnione, kompletne ankiety zostały poddane walidacji. Statystyczną analizę wyników przeprowadzono z wykorzystaniem programów Statistica 10.0 oraz Microsoft Excel 2010. Aby oszacować wiarygodność oraz rzetelność stworzonych ankiet, wykorzystano współczynnik korelacji wewnątrzklasowej (ICC) umożliwiający określenie poziomu zgodności. Wyliczono również współczynnik Cronbacha $\alpha$. Ankieta poddana walidacji składała się z dwóch części. Wszystkie pytania były typu zamkniętego, jedno- lub wielokrotnego wyboru odpowiedzi. Na podstawie prawidłowo 2-krotnie wypełnionych kwestionariuszy (95 sztuk) przeprowadzono analizę wiarygodności przygotowanej ankiety. Współczynnik korelacji wewnątrzklasowej pozwolił ocenić poziom rzetelności. Po uwzględnieniu zmian w ankietach i umieszczeniu szczegółowej informacji o możliwości wyboru kilku odpowiedzi w pytaniach współczynnik ICC wyniósł 0,78, co świadczy o zadowalającym stopniu powtarzalności.

\section{WYNIKI}

\section{Sumaryczne wyniki ankiet - część I ankiety:}

a) grupa badana: młodzież ze Szczecina w wieku 12-25 lat,

b) liczba ankiet oddana do wypełnienia: 100 sztuk,

c) liczba ankiet prawidłowo wypełnionych: 95 sztuk,

d) analizowana liczba respondentów: 95 osób,

e) procentowe wyniki formularza przedstawione w pracy przeliczono na ankiety poprawnie wypełnione, czyli 95, chyba że określono inaczej.

Wśród osób ankietowanych było 58\% mężczyzn oraz 42\% kobiet. Młodzież gimnazjalna w wieku 12-15 lat stanowiła 41\%, 28\% - licealiści w przedziale wiekowym 16-20 lat, a studenci w wieku 21-25 lat stanowili 31\%.

Na pytanie: Jak oceniasz swoją cerę? 34\% ankietowanych zadeklarowało posiadanie cery normalnej. Najmniej osób zaznaczyło cerę tłustą i suchą (odpowiednio 8\% i 6\%) - rycina 1.

Ponad połowa młodzieży (53\%) stwierdziła, że ma skłonność do wyprysków, 20\% ankietowanych wskazywało na skłonność do nadmiernego wydzielania sebum oraz zaczerwienienia cery. Zaledwie 8\% respondentów wskazało na skłonność do łuszczenia się cery (ryc. 2).

Większość ankietowanych (68\%) nie korzystała z usług gabinetu kosmetycznego, a zaledwie 3\% młodzieży wskazało na regularne wizyty w gabinecie kosmetycznym (1-2 razy w tygodniu lub 1-2 razy w miesiącu), odpowiedź „rzadko” zaznaczyło 25\% respondentów. Na pytanie: Czy wiesz, czym jest trądzik? aż 93\% respondentów odpowiedziało twierdząco. Uzyskane wyniki odnoszą się do 95 ankietowanych osób, które prawidłowo wypełniły ankietę. Do czynienia z tą chorobą miało $60 \%$ badanej młodzieży, natomiast 40\% nigdy nie chorowało na trądzik.

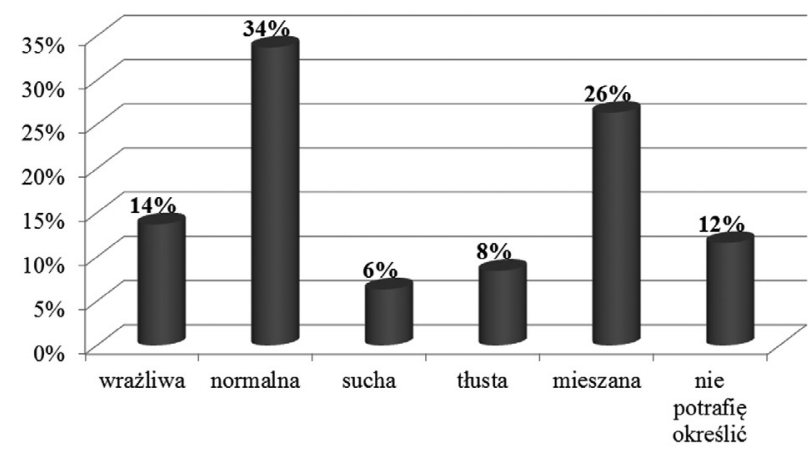

RYCINA 1. Samoocena cery respondentów

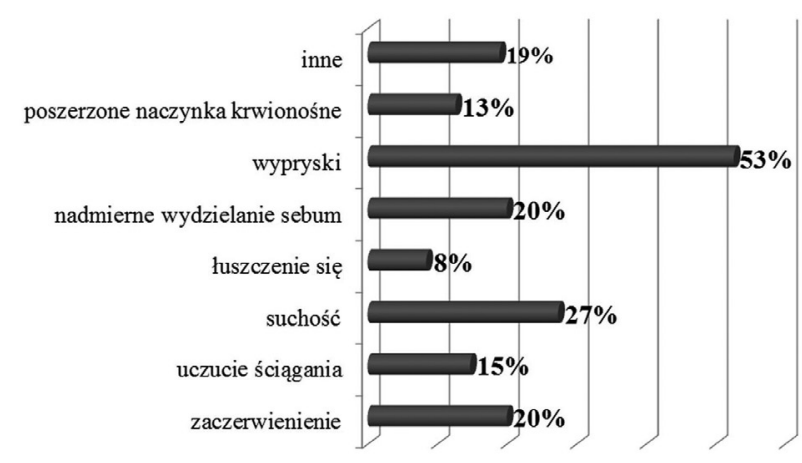

RYCINA 2. Skłonność cery do nieprawidłowości 


\section{Sumaryczne wyniki ankiet - część II ankiety:}

a) grupa badana: młodzież ze Szczecina w wieku 12-25 lat,

b) liczba ankiet oddana do wypełnienia: 100 sztuk,

c) liczba ankiet prawidłowo wypełnionych: 95 sztuk,

d) część II ankiety wypełniały osoby pozytywnie odpowiadające na pytanie 7 z części I (57 osób posiadających problemy trądzikowe),

e) liczba osób, które powinny, a nie wypełniły części II ankiety: 1 ,

f) analizowana liczba respondentów: 56 osób,

g) procentowe wyniki części II ankiety przeliczono na ankiety poprawnie wypełnione (56), chyba że określono inaczej.

Na pytanie: Czy u Twoich najbliższych (ojciec, matka) występował trądzik? 51\% ankietowanych odpowiedziało twierdząco; $40 \%$ nie posiadało wiedzy na ten temat, a $9 \%$ odpowiadało przecząco. Uzyskane wyniki odnoszą się do 55 ankietowanych osób, które prawidłowo odpowiedziały na pytanie. U większości ankietowanych (85\%) zmiany trądzikowe występowały na twarzy, 36\% twierdziło, że wykwity pojawiały się na plecach; $22 \%$ badanych zauważyło objawy trądziku na ramionach, a tylko $13 \%$ na dekolcie. Nieliczne osoby (4\%) miały wykwity na pośladkach i szyi. Uzyskane wyniki odnoszą się do 55 osób, które prawidłowo odpowiedziały na pytanie (ryc. 3).

Problem występowania trądziku młodzież rozwiązywała sama (32\%) lub udawała się po pomoc do apteki/drogerii lub gabinetu dermatologicznego (29\%); $20 \%$ ankietowanych nie widziało problemu i nie podejmowało żadnych działań, a 18\% korzystało z usług gabinetu kosmetycznego (ryc. 4).

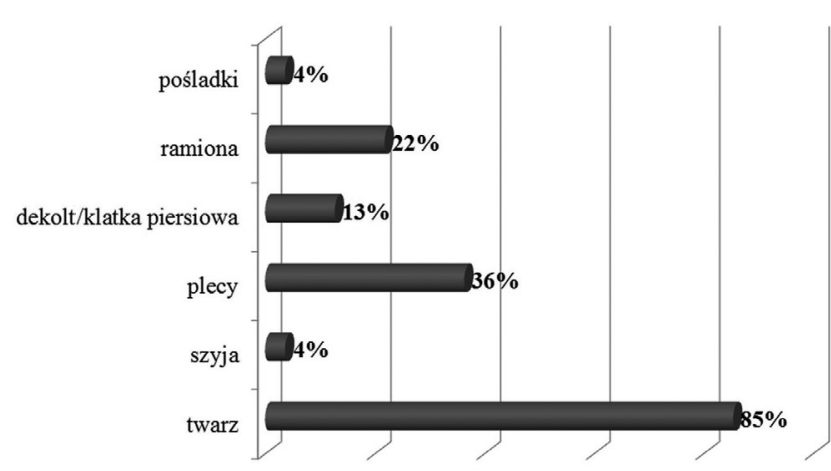

RYCINA 3. Miejsca występowania zmian trądzikowych

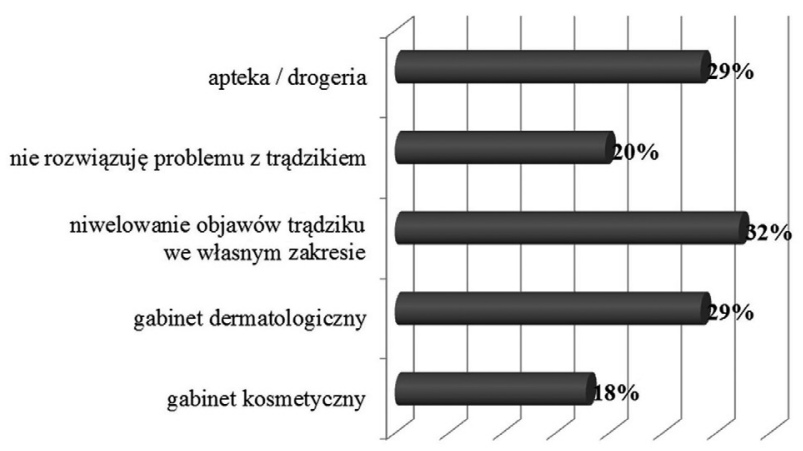

RYCINA 4. Miejsca, do których respondenci się udają, aby zlikwidować objawy trądziku

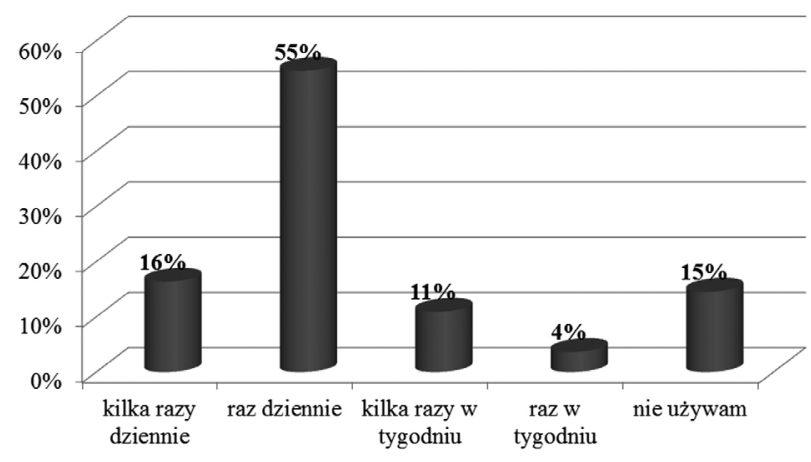

RYCINA 5. Częstotliwość stosowania specjalnych preparatów myjących i pielęgnujących do cery trądzikowej

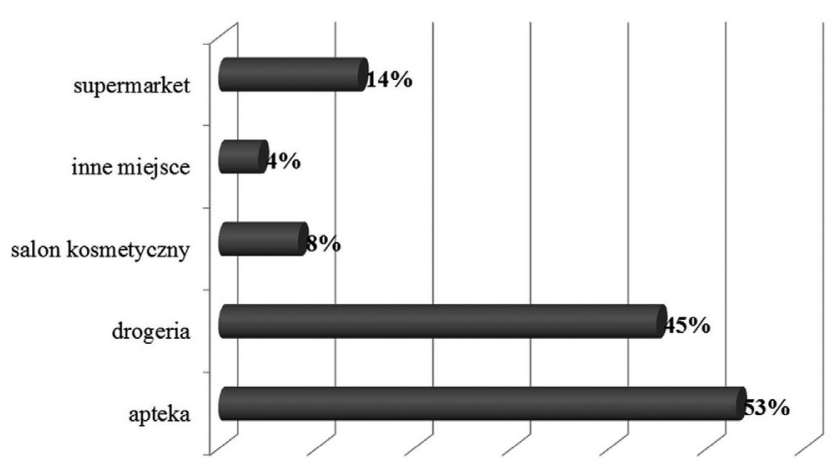

RYCINA 6. Miejsca zaopatrywania się w kosmetyki do pielęgnacji cery trądzikowej

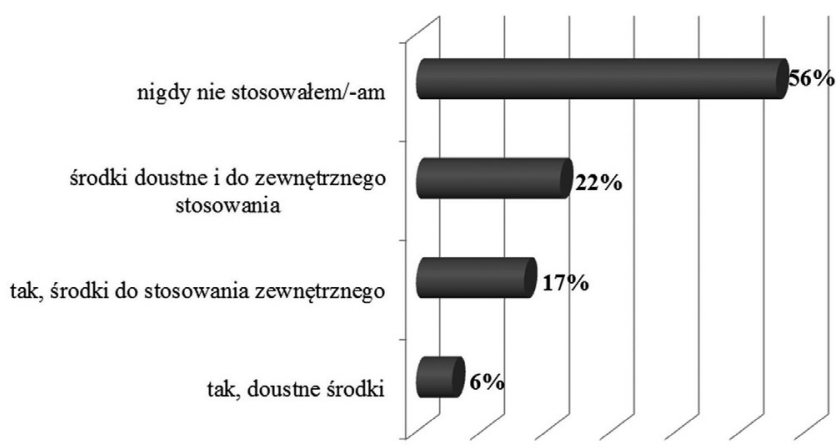

RYCINA 7. Stosowanie preparatów leczniczych

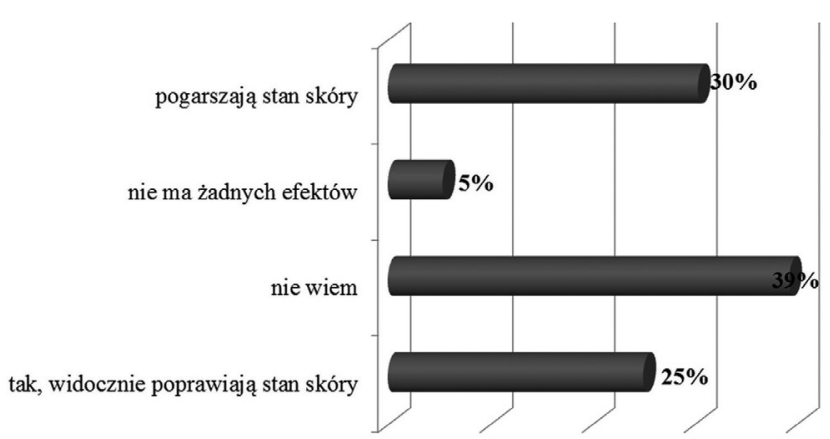

RYCINA 8. Wiedza respondentów na temat wpływu słońca na stan skóry trądzikowej 


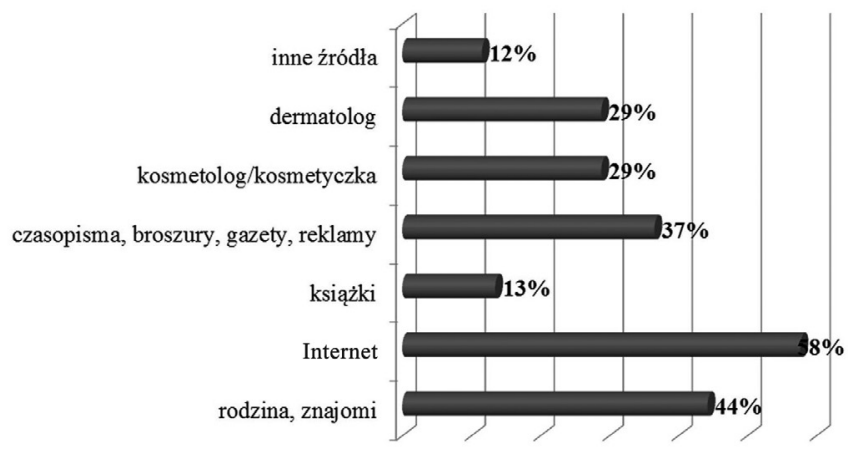

RYCINA 9. Źródła, z których młodzież czerpie wiedzę na temat trądziku

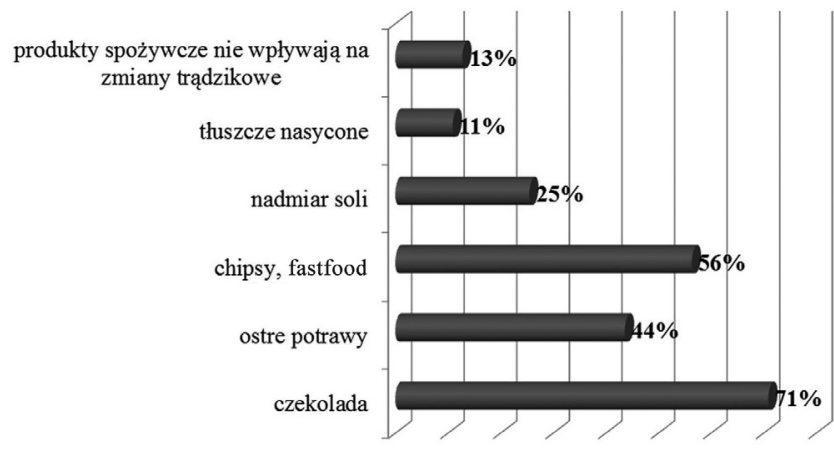

RYCINA 10. Wybrane produkty spożywcze nasilające zmiany trądzikowe

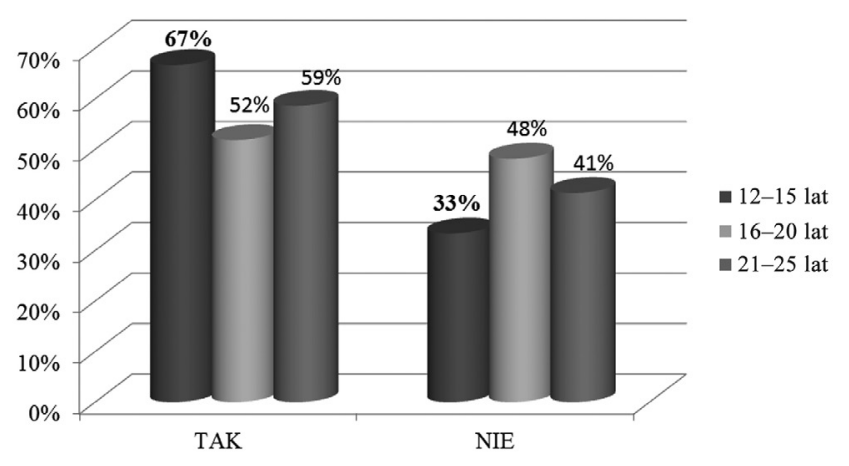

RYCINA 11. Zależność pomiędzy występowaniem trądziku a wiekiem ankietowanych

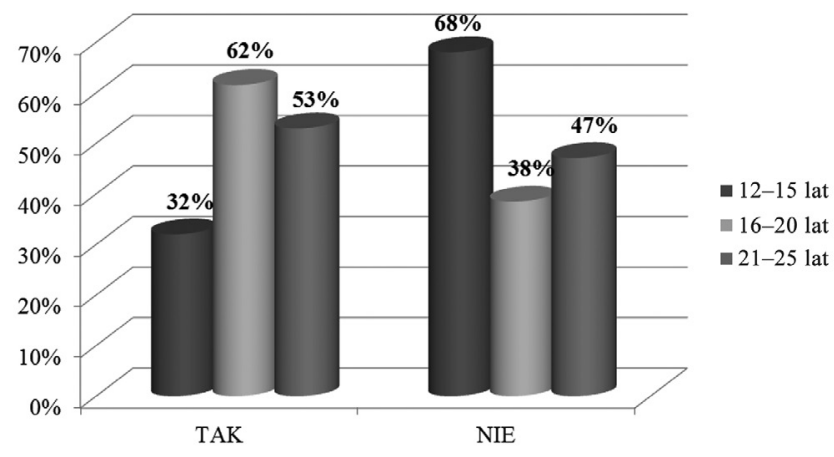

RYCINA 12. Zależność pomiędzy stosowaniem środków leczniczych a wiekiem ankietowanych
Preparaty myjące i pielęgnujące ankietowani stosowali głównie raz dziennie (55\%), a niektórzy kilka razy dziennie (16\%). Nieliczne osoby (4\%) stosowały preparaty zaledwie raz na tydzień. Uzyskane wyniki odnoszą się do 55 ankietowanych osób, które prawidłowo odpowiedziały na pytanie (ryc. 5).

Preparaty do cery trądzikowej kupowane były przede wszystkim w aptece (53\%) i drogerii (45\%); 14\% młodzieży zaopatrywało się w kosmetyki w supermarkecie, a w gabinetach kosmetycznych zaledwie 8\%. Uzyskane wyniki odnoszą się do 49 prawidłowo wypełnionych ankiet (ryc. 6).

Większość ankietowanych (56\%) nie korzystała nigdy z preparatów leczniczych, 22\% zażywała środki doustne i do stosowania zewnętrznego, zaś $17 \%$ respondentów korzystało tylko ze środków do stosowania zewnętrznego (ryc. 7). Nieliczne osoby (6\%) przyjmowały tylko doustne środki. Uzyskane wyniki odnoszą się do 54 ankietowanych, którzy prawidłowo odpowiedzieli na pytanie.

Kąpiele słoneczne i korzystanie z solarium według 30\% ankietowanych pogarsza stan skóry, zaś $25 \%$ uważało, że istotnie poprawia jej stan. Znaczna część młodzieży (39\%) nie miała zdania na ten temat (ryc. 8).

Najbardziej popularnym źródłem wiedzy na temat trądziku był Internet (58\%), następnie rodzina i znajomi (44\%) oraz czasopisma (37\%). Z wiedzy dermatologa i kosmetologa korzystało 29\% młodzieży, a z książek 13\% (ryc. 9). Uzyskane wyniki odnoszą się do 52 prawidłowo wypełnionych ankiet.

Zdecydowana większość młodzieży (71\%) zauważyła nasilenie zmian po spożyciu czekolady, $56 \%$ po chipsach i fastfoodach, a $44 \%$ dostrzegało zaostrzenie objawów po zjedzeniu ostrych potraw. Niektórzy respondenci (13\%) twierdzili, że produkty spożywcze nie mają wpływu na zmiany trądzikowe. Uzyskane wyniki odnoszą się do 55 ankietowanych, którzy prawidłowo odpowiedzieli na pytanie (ryc. 10).

Na pytanie: Czy nasilenie zmian trądzikowych występuje przed miesiączką? odpowiadały tylko kobiety (34 osoby). Nasilenie zmian trądzikowych przed miesiączką dostrzegła ponad połowa ankietowanych (59\%). Wyniki odnoszą się do 32 prawidłowo wypełnionych ankiet. Ponad połowa ankietowanych (51\%) mających problemy trądzikowe zaznaczyła, że choroba ta występowała w rodzinie. Aż 40\% respondentów z trądzikiem nie posiadało wiedzy na temat występowania trądziku w rodzinie. Nieliczni (9\%), którzy mieli problem z trądzikiem, stwierdzili brak jego występowania w rodzinie. Zdecydowana większość osób w wieku 12-15 lat (67\%) oraz 21-25 lat (59\%) miała trądzik (ryc. 11). Wyniki odnoszą się do 39 ankietowanych w wieku 12-15 lat, 27 ankietowanych w wieku 16-20 lat oraz 29 ankietowanych w wieku 21-25 lat.

Większość młodzieży w wieku 16-20 lat (62\%) i 21-25 lat (53\%) stosowała środki lecznicze na trądzik. W najmłodszej grupie wiekowej (12-15 lat) osób stosujących środki lecznicze było najmniej (32\%). Wyniki odnoszą się do 25 ankietowanych w wieku 12-15 lat, $13 \mathrm{w}$ wieku 16-20 lat oraz $17 \mathrm{w}$ wieku 21-25 lat (ryc. 12).

Wszystkie produkty spożywcze wymienione jako odpowiedzi w pytaniu 10 części II ankiety powodowały nasilenie zmian trądzikowych. Założono, że 100\% wiedzy było tożsame 


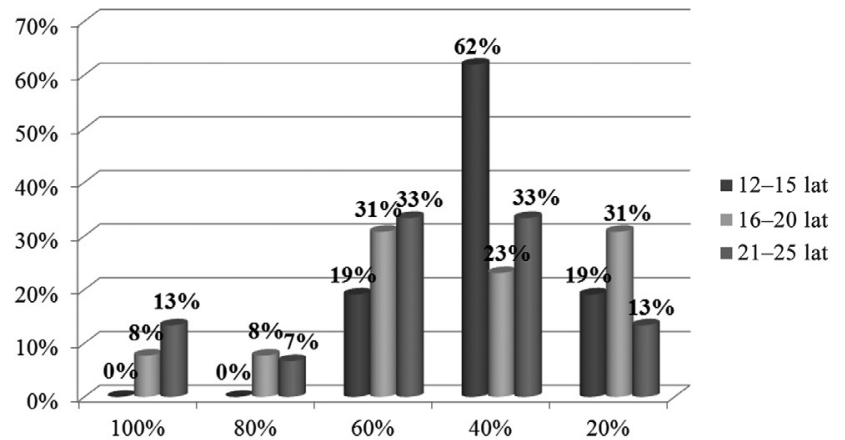

RYCINA 13. Zależność pomiędzy wiedzą na temat produktów mogących nasilić zmiany trądzikowe a wiekiem respondentów

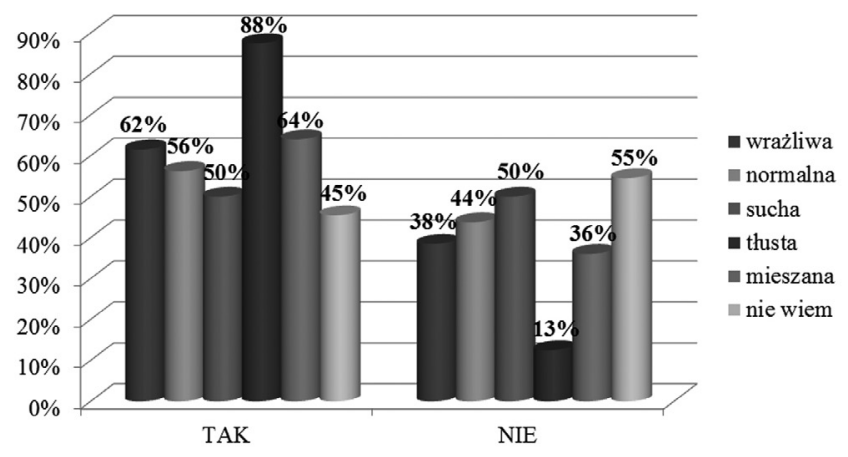

RYCINA 14. Zależność pomiędzy występowaniem trądziku a rodzajem cery

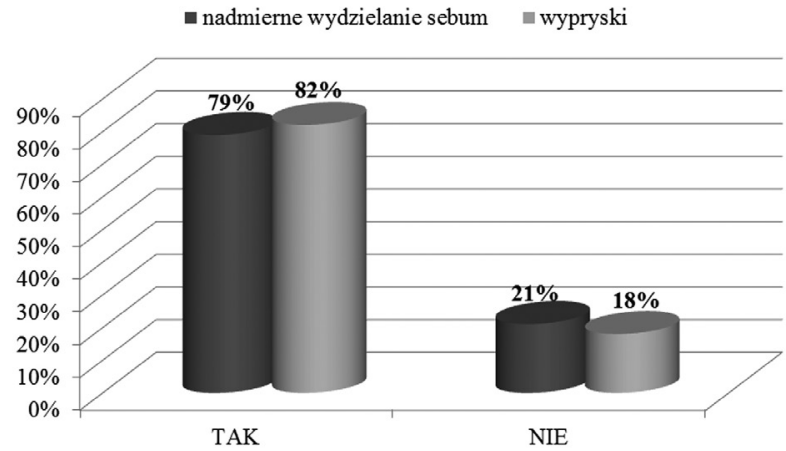

RYCINA 15. Zależność pomiędzy występowaniem trądziku a posiadaniem cery ze skłonnością do wyprysków oraz nadmiernego wydzielania sebum

z wyborem wszystkich 5 produktów spożywczych, a $20 \%$ wiedzy odnosi się do wyboru tylko jednego produktu; 49 ankietowanych przyznało, iż wymienione produkty mogą mieć wpływ na nasilenie zmian trądzikowych. Najmniejszą wiedzę na ten temat stwierdzono u najmłodszych respondentów (12-15 lat), którzy w 62\% przypadków wymieniali tylko 2 produkty żywnościowe. Wyniki uzyskano dla 21 ankietowanych w wieku 12-15 lat, 13-w wieku 16-20 lat oraz 15 respondentów w wieku 21-25 lat (ryc. 13).

Badania dotyczące zależności pomiędzy występowaniem trądziku a rodzajem cery (ryc. 14) wykazały, że wśród osób $\mathrm{z}$ cerą tłustą aż $88 \%$ miało trądzik. Duża część ankietowanych (ponad 60\%), która miała problemy z trądzikiem, posiadała cerę mieszaną oraz wrażliwą. Przedstawione wyniki odnoszą się do 13 osób z cerą wrażliwą, 32 - z cerą normalną, 6 - z cerą suchą i 8 - z cerą tłustą.

W badaniu wykazano, że skłonność do wyprysków oraz wydzielania sebum zwiększa częstotliwość występowania trądziku (ryc. 15). Wyniki opracowano w oparciu o 19 ankietowanych z cerą ze skłonnością do nadmiernego wydzielania sebum oraz 50 osób ze skłonnościami do wyprysków.

\section{DYSKUSJA}

Trądzik jest jedną z najczęściej występujących chorób dermatologicznych i schorzeń wieku młodzieńczego. Dotyka 80-100\% populacji w wieku 11-30 lat [6, 7]. Według Goodman [6] na dermatozę tę zapada 95-100\% 16-17-letnich chłopców i $83-85 \%$ dziewcząt w tym wieku. Łagodne zmiany typu trądzik zaskórnikowy, grudkowy i grudkowo-krostkowy dotykają ok. $85 \%$ populacji, a ciężkie postacie $15 \%$ [7]. Szczyt zachorowań przypada na 14.-17. r.ż. u kobiet i 16.-19. r.ż. w przypadku mężczyzn $[3,6]$. W badaniach własnych przeważały osoby poniżej 20. r.ż. Gimnazjaliści stanowili 41\%, licealiści $28 \%$, a studenci $31 \%$ ankietowanych. Większość respondentów posiadała trądzik (67\% osób w wieku 12-15 lat, 52\% ankietowanych w wieku 16-20 lat i 59\% młodzieży w wieku 21-25 lat). Wyniki przeprowadzonych badań wskazują, że u młodzieży szczecińskiej dermatoza ta występuje w mniejszym stopniu, niż wskazują na to dane z piśmiennictwa $[6,7,8]$. Prawdopodobnie uzależnione jest to od liczebności grupy badanej oraz wieku. Większość respondentów twierdziła, iż posiada cerę normalną lub mieszaną. Spośród osób z cerą tłustą aż 88\% miało trądzik. Ponadto osoby z cerą mieszaną oraz wrażliwą również w większości (ponad 60\%) dotknięte były tym schorzeniem. Wykazano, że nadmierne wydzielanie sebum oraz skłonność do wyprysków istotnie sprzyjały powstawaniu trądziku. Niespełna 20\% ankietowanych ze skłonnościami do tych niedoskonałości nie miało trądziku.

Według danych z piśmiennictwa najczęściej występującą postacią kliniczną jest trądzik zwykły, w którym oprócz zmian zaskórnikowych przeważają wykwity grudkowe i grudkowo-krostkowe [1, 6]. Specyficzne dla trądziku jest zajęcie okolic tzw. łojotokowych, szczególnie twarzy i pleców. W przypadku badań Brudnowskiego i Ziętkiewicza [9] trądzik u chłopców lokalizował się o 20\% częściej na dekolcie, szyi, plecach i pośladkach. Wyniki badań własnych potwierdziły lokalizację omawianych zmian w podobnej kolejności. Zmiany trądzikowe u młodzieży szczecińskiej występowały bowiem zdecydowanie najczęściej w rejonie twarzy (85\%), pleców (36\%), ramion (22\%), a także dekoltu/klatki piersiowej (13\%).

Z badań przeprowadzonych przez Rokowskq-Waluch i wsp. [10] wynika, że w związku ze zmianami skórnymi z porad dermatologa korzystało 63\% ankietowanych. Według Brudnowskiego i Ziętkiewicza [9] ok. 28\% chłopców i dziewcząt było leczonych przez lekarza dermatologa (85\%) lub lekarza rodzinnego (15\%). Młodzież szukała również pomocy w salonach kosmetycznych. Krasowska [11] podaje, że młodzież 
z reguły czerpała informacje o trądziku z mediów i prasy (68\%), od lekarza, kosmetyczki (42\%), rodziców (38\%), kolegów i koleżanek (25\%) oraz rodzeństwa (18\%). W badaniu Brudnowskiego i Ziętkiewicza [9] wiedza dziewcząt o trądziku pochodziła głównie z czasopism młodzieżowych i od koleżanek, a chłopcy najczęściej korzystali z Internetu. Tylko 6\% dziewcząt i chłopców informacje na ten temat uzyskało w szkole na lekcji biologii lub zajęciach wychowawczych. Wśród badanych w Szczecinie najpopularniejszym źródłem wiedzy był Internet (58\%), rodzina i znajomi (44\%), czasopisma (37\%), a na ostatnim miejscu dermatolog/kosmetolog (29\%). Większość szczecińskiej młodzieży (68\%) nigdy nie korzystała z usług gabinetów kosmetycznych/dermatologicznych. Otrzymane wyniki wskazują, że młodzież niechętnie korzysta z pomocy lekarza rodzinnego, dermatologa czy kosmetyczki, co również może mieć istotny wpływ na występowanie trądziku.

Tendencja do trądziku jest wrodzona, jednak sposób dziedziczenia nie został dokładnie określony. Sugeruje to dziedziczenie wieloczynnikowe. Prawdopodobieństwo wystąpienia schorzenia u dziecka, którego oboje rodziców chorowali na trądzik, wynosi ponad 50\% [1]. W badaniach epidemiologicznych wykazano, że schorzenie było obecne u jednego lub obojga rodziców. W pracy własnej większość ankietowanych (51\%), posiadających problemy trądzikowe stwierdziła, iż choroba ta występowała także w rodzinie.

Jeśli chodzi o wpływ diety na zaostrzenie zmian trądzikowych, zdania są podzielone. Według Wolskiej [7] wpływ pokarmu na zaostrzenie zmian w trądziku, głównie węglowodanów, występuje rzadko i dotyczy ok. 10\% pacjentów. Z kolei Krasowska [11] mówi o 5\% chorych, u których czekolada czy ostre przyprawy mogą powodować nasilenie zmian chorobowych. W badaniach Rokowskiej-Waluch i wsp. [10] aż 70\% respondentów dostrzegało jednak związek między rodzajem spożywanych pokarmów a nasileniem zmian trądzikowych. Ankietowani na pierwszym miejscu wymienili czekoladę, chipsy i fastfoody, a także produkty charakteryzujące się wysokim indeksem glikemicznym jako produkty nasilające tę dermatozę. Tylko 13\% respondentów stwierdziło, iż dieta nie wpływa na nasilenie objawów. Świadomość na temat produktów, które wpływają na nasilenie zmian trądzikowych, uzależniona jest od wieku: najmniejsza występuje wśród gimnazjalistów, a wraz $\mathrm{z}$ wiekiem wzrasta.

Sięganie po środki lecznicze również związane jest z wiekiem ankietowanych. Większość młodzieży w wieku 16-25 lat stosuje środki lecznicze na trądzik, jednak zależność ta wzrasta wraz z wiekiem ankietowanych. W świetle przeprowadzonych badań 93\% młodych ludzi twierdzi, że wie, czym jest trądzik, lecz otrzymane wyniki dotyczące pielęgnacji oraz metod postępowania z cerą trądzikową sugerują, że nie jest to poparte odpowiednią wiedzą. Świadomość ta zwiększa się z wiekiem ankietowanych, co świadczy, iż młodzież gimnazjalna i licealna nie posiada odpowiednich informacji. W świetle dostępnego piśmiennictwa i wyników badań własnych można przypuszczać, że istotnym faktem jest brak edukacji młodzieży w tym zakresie.

\section{WNIOSKI}

1. Czynnikami mogącymi mieć wpływ na występowanie trądziku może być rodzaj cery, skłonności do niedoskonałości oraz stan wiedzy o trądziku wśród młodzieży gimnazjalnej, licealnej i studiującej w Szczecinie, który jest zróżnicowany i niepełny.

2. Ważne jest dokształcanie i uświadamianie młodzieży, jak sobie radzić z trądzikiem, jak leczyć tę chorobę i jak pielęgnować cerę trądzikową, gdyż schorzenie to występuję często już w młodym wieku, wywierając negatywny wpływ na aspekt emocjonalny i socjalny życia.

\section{PIŚMIENNICTWO}

1. Braun-Falco O., Plewig G., Wolff H.H., Burdgdorf W.H.C.: Dermatologia. Wyd. Czelej, Lublin 2004, 993-1002.

2. Czernielewski A.: Zarys chorób skóry, błony śluzowej, jamy ustnej i wenerycznych. PZWL, Warszawa 1982, 302-307.

3. Adamski Z., Kaszuba A.: Dermatologia dla kosmetologów. Wyd. Elsevier Urban \& Partner, Wrocław 2010, 54-58.

4. Krasowska D.: Etiopatogeneza i obraz kliniczny trądziku pospolitego. Dermatol Estet. 2006, 43 (2), 67-71.

5. Janda K., Chwilkowska M.: Trądzik pospolity - etiologia, klasyfikacja, leczenie. Ann Acad Med Stetin. 2014, 60 (2), 13-18.

6. Goodman G.J.: Patofizjologia blizn potrądzikowych - krótki opis mechanizmu ich powstawania. Dermatol Estet. 2002, 18 (1), 22-28.

7. Wolska H.: Dermatologia w praktyce. PZWL, Warszawa 2009, 144-148.

8. Kaszuba A.: Trądzik pospolity: leczenie miejscowe preparatami prostymi w terapii naprzemiennej. Dermatol Prakt. 2010, 4 (2), 9-17.

9. Brudnowski D., Ziętkiewicz M.: Trądzik młodzieńczy - analiza porównawcza dziewcząt i chłopców. Post Dermatol Alergol. 2003, 20 (5), 311-315.

10. Rokowska-Waluch A., Gąska A., Pawlaczyk M.: Przebieg trądziku zwykłego w ocenie pacjentów. Post Dermatol Alergol. 2009, 26 (1), 34-40.

11. Krasowska D.: Trądzik. Diagnostyka i leczenie. Wyd. Czelej, Lublin 2009, 115-120, 170.

\section{ANKIETA - WERSJA PO WALIDACJI}

Ankieta mająca na celu zbadanie poziomu wiedzy na temat trądziku wśród młodzieży w Szczecinie. Ankieta jest anonimowa.

\section{CZĘŚĆ I}

1. Płeć
a) kobieta
b) mężczyzna

2. Wiek
a) $12-15$
b) $16-20$
c) $21-25$

3. Jak oceniasz swoją cerę? (1 odpowiedź)
a) wrażliwa
b) normalna
c) sucha
d) tłusta
e) mieszana
f) nie potrafię określić 
4. Twoja cera ma skłonności do (możliwość wyboru kilku odpowiedzi)
a) zaczerwienienia
b) uczucia ściągania
c) suchości
d) łuszczenia się
e) nadmiernego wydzielania sebum (łoju)
f) wyprysków
g) poszerzonych naczynek krwionośnych
h) inne

5. Jak często korzystasz z zabiegów pielęgnacyjnych w gabinecie kosmetycznym?
a) 1-2 razy w tygodniu
b) 1-2 razy w miesiącu
c) rzadko
d) wcale

6. Czy wiesz, czym jest trądzik?
a) tak
b) nie

7. Czy kiedykolwiek miałaś/miałeś trądzik?
a) tak
b) nie

OSOBOM, KTÓRYCH NIE DOTYCZY PROBLEM TRĄDZIKU, DZIĘKUJĘ ZA WYPEŁNIENIE CZĘŚCI I ANKIETY. OSOBY, KTÓRE MAJĄ OBJAWY TRĄDZIKU, PROSZĘ O WYPEŁNIENIE CZĘŚCI II.

\section{CZĘŚĆ II}

1. Czy u Twoich najbliższych (ojciec, matka) występował trądzik?
a) tak
b) nie występował
c) nic mi o tym nie wiadomo

2. Gdzie umiejscowione są zmiany (bądź były) trądzikowe? (możliwość wyboru kilku odpowiedzi)
a) twarz
b) szyja
c) plecy
d) dekolt/klatka piersiowa
e) ramiona
f) pośladki

3. Do jakiego miejsca kierujesz się, aby rozwiązać problem występowania trądziku? (możliwość wyboru kilku odpowiedzi)

a) gabinet kosmetyczny

b) gabinet dermatologiczny

c) próbuję niwelować objawy trądziku we własnym zakresie w domu

d) nie próbuję i/lub nie próbowałem rozwiązać problemu $\mathrm{z}$ trądzikiem

e) apteka/drogeria
4. Jak często używasz specjalnych preparatów myjących (żel, tonik, pianka)/pielęgnacyjnych (krem, maść, maseczka) do skóry trądzikowej?
a) kilka razy dziennie
b) raz dziennie
c) kilka razy w tygodniu
d) raz w tygodniu
e) nie używam (proszę przejść do pytania 6)

5. Gdzie kupujesz kosmetyki do pielęgnacji skóry trądzikowej? (możliwość wyboru kilku odpowiedzi)
a) w aptece
b) w drogerii
c) w salonie kosmetycznym
d) w innym miejscu
e) w supermarkecie

6. Czy stosujesz lub stosowałeś/-aś preparaty lecznicze?
a) tak, doustne środki
b) tak, środki do stosowania zewnętrznego
c) środki doustne i do zewnętrznego stosowania
d) nigdy nie stosowałem/-am

7. Jak sądzisz, czy zażywanie kąpieli słonecznych lub korzystanie z solarium poprawiają stan skóry trądzikowej?
a) tak, widocznie poprawiają stan skóry
b) nie wiem
c) nie ma żadnych efektów poprawy
d) pogarszają stan skóry

8. Z jakich źródeł czerpiesz informacje na temat trądziku: pielęgnacji, leczenia i ogólnych wiadomości? (możliwość wyboru kilku odpowiedzi)
a) od rodziny, znajomych
b) $\mathrm{z}$ Internetu
c) $\mathrm{z}$ książek
d) z czasopism, gazet, broszur, reklam
e) od kosmetologa/ kosmetyczki
f) od lekarza dermatologa
g) z innych źródeł

9. Które z wymienionych produktów mogą według Ciebie nasilić zmiany trądzikowe? (możliwość wyboru kilku odpowiedzi)
a) czekolada
b) ostre potrawy
c) chipsy, fastfoody
d) nadmiar soli
e) tłuszcze nasycone
f) produkty spożywcze nie wpływają na zmiany trądzikowe

10. *Pytanie dla płci żeńskiej.

Czy występuje nasilenie zmian trądzikowych przed miesiączką?

a) tak

b) nie 